\title{
KOKEITA AUTOMAATTIRUOKINNAN JÄRJESTÄMISEKSI MEIJERISIKALASSA
}

\author{
P. SaArinen, E. Syrjänen ja Vuokko Hyvärinen \\ Helsingin Yliopiston Kotieläintieteellinen laitos, Viikin koetila, Malmi
}

Saapunut 19. 5. 1956

Ruokinnan automatisointi on viime vuosien aikana saanut kotieläinten ruokinnassa jatkuvasti kasvavaa huomiota osakseen. Eräissä tapauksissa automatisointi on sikaloissakin suhteellisen helposti toteutettavissa. Sikaloissa rehuautomaattien käyttöön liittyy kuitenkin yleisesti ruhojen liikarasvoittumisen vaara. Erityisen haitallisena tämä liikalihominen esiintyy pekonisikojen kasvatuksessa.

Silavakerroksen paksuus ruhon eri osissa on ensi sijassa perinnöllisistä tekijöistä johtuva ominaisuus, mutta tähän samoinkuin lihakkuuteen voidaan kuitenkin varsin huomattavassa määrässä vaikuttaa myös ruokinnalla. - Sikoja käsin ruokittaessa silavan paksuutta voidaan säännöstellä rajoittamalla rehuannoksen ry-määrää etenkin kasvukauden jälkipuoliskolla $(8,9,10,6,14,4,5,15)$. Tällainen ruokinnan vähentäminen on kuitenkin omiaan hidastamaan sian kasvua ja eräissä tapauksissa myös lisäämään kasvukiloa kohden tarvittavaa rehun määrää. Huonoin rehun hyväksikäyttötulos ja samalla voimakkain ruhon rasvoittuminen on kuitenkin yleensä tuloksena silloin kun käytetään kasvatuksen alkuvaiheessa niukkaa ja loppuvaiheessa runsasta energiaruokintaa (2).

Bull ja Longwell totesivat kokeissaan jo v. 1929 (3), että sikojen perinnöllisistä ominaisuuksista riippumatta automaattiruokinta johtaa yleensä suhteellisesti voimakkaampaan ruhon rasvoittumiseen. Liikarasvoittumisen estämiseksi sikojen automaattiruokinnan yhteydessä on kokeiltu erilaisten täyttävämpien väkirehujen, kuten leseiden ja kaurarehujauhojen vieläpä heinäsilpunkin käyttöä rehuseoksissa $(7,4)$.

Hutchinson (7) on tutkinut väkirehuseokseen lisätyn luserniheinäsilpun vaikutusta sikojen lihotustuloksiin automaattiruokinnan yhteydessä. Hän lisäsi heinäsilppua koeryhmien rehuun n. 45 kilon elopainorajasta alkaen asteittain 5-15 
prosenttia. Tämän lisän vaikutuksesta eläinten kasvunopeus väheni 10 - 12 prosenttia, mutta samalla myös selkäsilavan paksuus pieneni (toisessa kokeessa noin 15 prosentilla).

Erityisesti liiallisen raakakuitumäärän rehussa on todettu hidastavan sikojen kasvua ja alentavan rehun tuotantovaikutusta. Käyttäessään kauraa kuitupitoisena rehuna väkirehuseoksessa NoRDFELDT (12) sai raakakuidun optimimääräksi sian rehuannoksessa $7.4-8.4 \%$ rehun kuiva-aineen määrästä. Antaessaan kuitulisän jauhetun vehnänoljen muodossa hän sai raakakuidun optimimääräksi alemman arvon eli $4.0 \%$. AxELsson (1) totesi käyttäessään jauhettua vehnänolkea kuitupitoisena lisänä lihotussikojen väkirehuseoksissa lisäkasvun olevan nopeimman silloin, kun rehun kuiva-aine sisälsi raakakuitua $6.57 \%$. Paras rehun hyväksikäyttö ja paras tuotantovaikutus rehulla saavutettiin kuitenkin silloin, kun kuivaaineen kuitupitoisuus oli $7.26 \%$.

Meijerisikaloissa, joita pidetään etupäässä heran markkinoimistarkoituksessa, on yleensä pyrittävä suhteellisesti runsaaseen heran ja suhteellisesti vähäiseen väkirehujen käyttöön. Poijärven, PARTASen ja PAKARISen (13) suorittamien tutkimusten mukaan 40-100 kg:n painoisten sikojen ruokintaan voidaan käyttää heraa $40 \%$ jopa $70 \%$ rehuannoksen ry-määrästä. Tätä suuruusluokkaa olevia heramääriä käytettäessä sikojen valkuaistarve voidaan sekä määrän että laadun suhteen tyydyttää 35-40 kilon painorajasta alkaen pelkällä hera-viljaruokinnalla. Tähän perustuen meijerisikaloissamme onkin ryhdytty käyttämään ruokintatapaa, jossa sioille on annettu eri ikäkausina $60-30 \%$ ruokintanormien edellyttämästä päivittäisestä ry-määrästä viljatuotteina sekä lisäksi heraa vapaasti. Milloin käytettävissä oleva heran määrä ei kuitenkaan riitä yhdessä vilja-annoksen kanssa tyydyttämään normien mukaista päivittäistä ry-tarvetta, niin puuttuva osa korvataan väkirehuseoksella. Tämäntapaisella ruokinnalla on saavutettu sekä rehun hyväksikäytön että tuotteiden laadun kannalta tyydyttäviä tuloksia.

Ryhtyessämme pari vuotta sitten suunnittelemaan ruokinnan automatisointia meijerisikaloissa koesuunnitelmassa kiinnitimme huomiota erityisesti kahteen seikkaan. Ensinnäkin näytti liikalihomisen estämiseksi ja tyydyttävän runsaan herankulutuksen varmistamiseksi olevan tärkeää, että väkirehun osuutta voitaisiin automaattiruokinnassa rajoittaa yhtä tehokkaasti kuin sikoja käsin ruokittaessa. Toiseksi tämä rajoitus olisi saatava aikaan ilman edellä mainittua Hutchinsonin toteamaa kasvunopeuden vähenemistä tai rehun tuotantovaikutuksen pienenemistä.

Edellä esitettyjen koetulosten nojalla asiaa tarkasteltaessa tällainen ratkaisu näytti teoreettisesti mahdolliselta. Hutchinsonin y.m. koetulosten mukaan oli toisaalta todennäköistä, että verraten pienet, $5-15 \%$ :n suuruiset karkearehujen lisäykset väkirehuseokseen voivat riittävän tehokkaasti rajoittaa rehuautomaateista vapaasti saatavissa olevan väkirehuseoksen syöntiä ja vastaavasti lisätä heran osuutta rehuannoksessa. Mikäli heran kulutus täten saataisiin nousemaan riittävän suureksi, niin toisaalta taas suuremmatkaan ehkä tarpeelliseksi osoittautuvat karkearehulisät kuivarehuannoksessa eivät todennäköisesti tulisi nostamaan koko rehuannoksen kuiva-aineen raakakuitupitoisuutta niin suureksi, että rehun tuotantovaikutuksen alenemista olisi tästä syystä odoteftavissa. Kun erilaisten 
kuitupitoisten rehujen vaikutuksista sikojen väkirehuseoksissa ei kuitenkaan ollut vielä riittävää kokemusta olemassa, niin väkirehujen syöntiä hidastavia täyteaineita otettiin kokeisiin kaksi, nimittäin sialla helpommin sulava kuivattu sokerijuurikasleike sekä heinäjauho.

\section{Kokeiden järjestely}

Edellä esitellyn teoreettisen ratkaisun soveltamismahdollisuuksien selvittämiseksi kirjoittajien toimesta on tähän mennessä suoritettu kaksi varsinaista ruokintaja kasvatuskoetta. Lisäksi on erilaisia sovellutuksia kokeiltu käytännön olosuhteissa.

Ensimmäinen ruokintakoe suoritettiin Meijerien Keskusosuusliike Valion Ylitornion sikalassa aikana 4/6—8/12 1955 kolmella 12 porsaan ryhmällä. Koetta varten yhdeltä tilalta ostetut pahnueet olivat lähetettäessä sekaantuneet ja porsasryhmät oli valittava silmämääräisesti. Koevirheen pienentämiseksi ryhmät oli muodostettava verraten suuriksi. Vertailtavina tässä kokeessa oli a) normien mukainen vilja-heraruokinta, b) vapaa automaattiruokinta, jossa vertailuryhmän saamaan väkirehuseokseen oli sen kulutuksen rajoittamiseksi lisätty kuivattua sokerijuurikasleikettä, sekä c) vapaa automaattiruokinta käyttämällä kuitupitoisena lisänä kuivarehuseoksessa heinäjauhoa.

Toiseen ruokintakokeeseen, joka suoritettiin aikana 11/11 -55-6/5 -56 kahdella 10 porsaan ryhmällä, porsaat valittiin pahnueittain yhtä monta samantapaista porsasta kustakin pahnueesta kumpaankin koeryhmään. Tässä kokeessa oli vertailtavana toisaalta normien mukainen käsinruokinta ja toisaalta automaattiruokinta käyttämällä kuivarehun syöntiä rajoittavana lisänä melassileikettä. Ryhmien koko ja tasaisuus ilmenee yksityiskohtaisemmin taulukosta 4.

Ruokinta suoritettiin ryhmäruokintana. Vertailuryhmälle punnittiin ruokintasuunnitelman mukaiset väkirehumäärät kahdesti päivässä. Varsinaiset koeryhmät taas saivat syödä kaikkia rehuja vapaasti, ja väkirehut punnittiin rehuautomaattiin suurempina erinä. Hera syötettiin ruuhista, joihin sitä mitattiin tarpeen mukaan, ja tähteeksi jäänyt osa poistettiin ja mitattiin kerran päivässä. Eläimet punnittiin kerran viikossa.

\section{Ruokinta}

Perusrehu oli ensimmäisessä kokeessa kokoonpantu sellaisista väkirehuista, joiden kuitupitoisuus oli jo sinänsä verrattain korkea. Tämä seos sisälsi $50 \%$ kaurajauhoja, $30 \%$ maissia ja $20 \%$ vehnänleseitä. Toisessa kokeessa taas käytettiin verrattain vähän kuitua sisältävää maissi- vehnänrehujauhoseosta.

Sikojen tarvitsemat ry- ja sv-määrät laskettiin Hanssonin esittämien normilukujen nojalla, jotka normit voidaan nähdä myös taulukoista 1 ja 3 . Myös muiden ravintoaineiden likimääräiset tarveluvut on esitetty taulukossa 1.

Viljan täydennykseksi tarvittava valkuaismäärä laskettiin saatavaksi kuoritusta maidosta ja herasta. Vilja-hera-rehuannoksen kivennäiskokoonpanon täydentämi- 
Taulukko 1. Kasvavien sikojen likimääräinen ravinnontarve.

Table 1. Calculated dietary requirements of growing pigs.

\begin{tabular}{|c|c|c|c|c|c|}
\hline \multirow[t]{2}{*}{$\begin{array}{l}\text { Tarve päivässä } \\
\text { Required daily }\end{array}$} & & \multicolumn{4}{|c|}{$\begin{array}{l}\text { Painoluokka, kg } \\
\text { Weight class., kg }\end{array}$} \\
\hline & & $15-20$ & $40-45$ & $70-75$ & $90-95$ \\
\hline $\begin{array}{l}\text { Rehuyksiköitä } \\
\text { Sc. feed units }\end{array}$ & & 0.9 & 1.9 & 2.8 & 3.3 \\
\hline $\begin{array}{l}\text { Sulavaa valkuaista (sv) } \\
\text { Dig. prot. }\end{array}$ & g & 117 & 220 & 270 & 300 \\
\hline $\begin{array}{l}\text { Kalsiumia }(\mathrm{Ca}) \\
\text { Calcium }\end{array}$ & g & 7 & 11 & 12 & 12 \\
\hline $\begin{array}{l}\text { Fosforia (P) } \\
\text { Phosphorus }\end{array}$ & g & 4 & 8 & 9 & 9 \\
\hline $\begin{array}{l}\text { Natriumia }(\mathrm{Na}) \\
\text { Sodium }\end{array}$ & g & $2-3$ & $5-6$ & $8-9$ & $10-11$ \\
\hline $\begin{array}{l}\text { Kaliumia }(\mathrm{K}) \\
\text { Potassium }\end{array}$ & g & $1-2$ & $3-4$ & $4-5$ & $5-6$ \\
\hline $\begin{array}{l}\text { Rautaa }(\mathrm{Fe}) \\
\text { Iron }\end{array}$ & $\mathrm{mg}$ & 20 & 40 & 50 & 60 \\
\hline $\begin{array}{l}\text { Mangaania }(\mathrm{Mn}) \\
\text { Manganese }\end{array}$ & $\mathrm{mg}$ & 10 & 20 & 25 & 30 \\
\hline $\begin{array}{l}\text { Kuparia }(\mathrm{Cu}) \\
\text { Copper }\end{array}$ & $\mathrm{mg}$ & 10 & 20 & 25 & 30 \\
\hline $\begin{array}{l}\text { Kobolttia }(\mathrm{Co}) \\
\text { Cobalt }\end{array}$ & $\mathrm{mg}$ & 0.1 & 0.2 & 0.2 & 0.3 \\
\hline $\begin{array}{l}\text { Jodia }(\mathrm{J}) \\
\text { Iodine }\end{array}$ & $\mathrm{mg}$ & 0.1 & 0.2 & 0.3 & 0.4 \\
\hline $\begin{array}{l}\text { A-vitamiineja } \\
\text { Vit. A. }\end{array}$ & Kv.y. & 1000 & 2000 & 4000 & 5500 \\
\hline $\begin{array}{l}\text { D-vitamiineja } \\
\text { Vit. } D\end{array}$ & Kv.y. & 100 & 250 & 350 & 400 \\
\hline $\begin{array}{l}\mathrm{B}_{1} \text {-vitamiinia } \\
\text { Vit. } B_{1}\end{array}$ & $\mathrm{mg}$ & 1.5 & 2.5 & 3.5 & 4 \\
\hline $\begin{array}{l}\mathrm{B}_{2} \text {-vitamiinia } \\
\text { Vit. } B_{2}\end{array}$ & $\mathrm{mg}$ & 2 & 4 & 5 & 6 \\
\hline $\begin{array}{l}\text { Niasiinia } \\
\text { Niacin }\end{array}$ & $\mathrm{mg}$ & 7 & 13 & 17 & 20 \\
\hline
\end{tabular}

seksi ja tasapainoistamiseksi suunniteltiin meikäläisen heran koostumus huomioonottaen kivennäissuolaseos, jonka prosenttinen kokoomus oli seuraava:

Liitua

Ruokintakalkkia

Rehuluujauhoja

Ruokasuolaa

Rautasulfaattia

Mangaanisulfaattia

Kuparisulfaattia

Kobolttisulfaattia

Kaliumjodidia
Kivennäissuolaseos

$\begin{array}{r}30.000 \% \\ 30.000 \% \\ 30.000 \% \\ 9.720 \% \\ 0.100 \% \\ 0.100 \% \\ 0.070 \% \\ 0.005 \% \\ 0.005 \% \\ \hline\end{array}$

$100.000 \%$ 
Tämä kivennäisseos on tarkoitettu nimenomaan meikäläisen hera-viljaruokinnan täydentämiseen, eikä se mm. sisällä kuivarehuruokinnassa tarpeelliseksi osoittautunutta sinkkiä. Kun Lääke-Oy ryhtyi jo ennen varsinaisen ruokintakokeen alkamista suuremmassa mittakaavassa valmistamaan ja myymään ylläesitettyä kivennäissuolaseosta, niin tämä "Hera-Röhö»-niminen seos otettiin käytäntöön myös tässä kokeessa.

Tarvittavat vitamiinit, erityisesti B-ryhmän vitamiinit voidaan sopivalla rehun valinnalla saada perusrehussa. Niinpä esimerkiksi $B_{2}$-vitamiinia on suhteellisen runsaasti sekä kuoritussa maidossa että herassa, ja niasiinia taas erityisesti leseissä. A-vitamiinia tai karotiinia voidaan saada keltaisesta maissista, AIV-rehusta ja luserni- tai apilajauhoista jne. Ensimmäisessä ruokintakokeessa käytettävissä olleiden väkirehujen laadun ja erityisesti D-vitamiinin tarpeen tyydyttämisen huomioonottaen erillisen stabilisoidun A-D-vitamiinivalmisteen lisääminen väkirehuseokseen näytti kuitenkin tässä tapauksessa sopivimmalta ratkaisulta. Vitamiinivalmisteeksi valittiin kaupassa oleva Lääke-Oy:n valmistama Deba-vitan, joka sisältää paitsi D- ja A- myös E- ja B-vitamiineja. Riittävän D-vitamiinin ja samalla myös muiden vitamiinien saannin varmistamiseksi Deba-vitan-valmistetta käytettiin rehuseoksessa $0.2 \%$.

Edellä esitetyt lisät huomioonottaen perusrehun kokoomus muodostui ensimmäisessä ruokintakokeessa seuraavaksi:

\begin{tabular}{lr} 
Kauraa (jauhettua) & Perusrehu 1. \\
Maissia (jauhettua) & $48.9 \%$ \\
Vehnänlesettä & $29.3 \%$ \\
"Deba-vitan"-valmistetta & $19.6 \%$ \\
"Hera-Röhö»-kivennäissuolaseosta & $0.2 \%$ \\
\cline { 2 - 2 } & $2.0 \%$ \\
\hline
\end{tabular}

Loppulihotusvaiheessa käytettiin kuitenkin 20 päivän ajan kuivarehuseosta, joka sisälsi $50 \%$ ylläesitettyä seosta ynnä $50 \%$ maissia.

Perusrehun verrattain korkean raakakuitupitoisuuden $(6,5 \%)$ ja sen seikan huomioonottaen, että samaa seosta voitaisiin käyttää koko kokeen ajan, automaattiryhmien väkirehuun lisättävän sokerijuurikasleikkeen ja heinäjauhon määrä rajoitettiin hyvin vähäiseksi eli vain 5 prosentiksi seoksen määrästä.

Toisessa ruokintakokeessa (11/11 -55-30/4 -56) käytettiin aluksi 62 vuorokauden ajan samaa perusrehua kuin ensimmäisessä kokeessa ja sen jälkeen toista maissivaltaista seosta, johon valkuaispitoisuuden nostamiseksi oli lisätty mm. $5 \%$ Vaasan Höyrymyllyn valmistamaa "Täysivoima»-nimistä sikojen valkuaisväkirehuseosta. Toisessa kokeessa alkuvaiheen jälkeen käytetyn perusrehun kokoomus oli yksityiskohtaisemmin seuraava:

\begin{tabular}{lr} 
Maissia (jauhettua) & Perusrehu 2. \\
Vehnänrehujauhoja & $46.0 \%$ \\
Vehnänlesettä & $25.0 \%$ \\
"Täysvoima"-väkirehuseosta & $22.0 \%$ \\
"Deba-vitan"-valmistetta & $5.0 \%$ \\
"Hera-Röhö»-kivennäissuolaseosta & $0.2 \%$ \\
\cline { 2 - 2 } & $1.8 \%$ \\
\hline
\end{tabular}


Syönnin hidastajana toisen kokeen automaattiryhmän väkirehuseoksessa käytetyn melassileikkeen määrä oli samoin kuin edellisessä kokeessa $5 \%$ kuivarehuseoksen määrästä.

Kaikki rehuseokset valmistettiin Keskusosuusliike Hankkija r.l.:n Kolpin sekoittamossa ja ensimmäisen kokeen rehuanalyysit suoritettiin Valtion Maan-

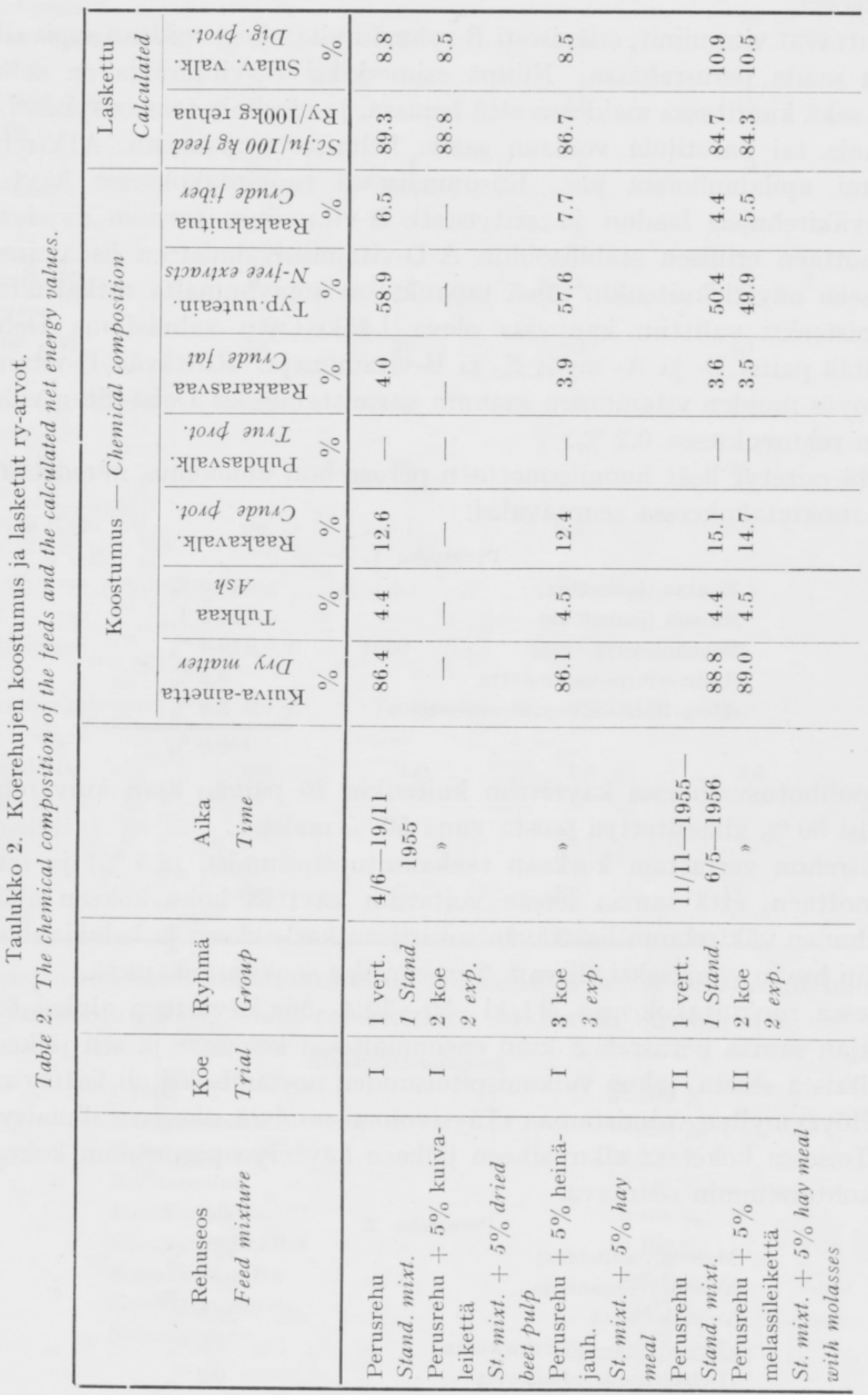


viljelyskemiallisessa laboratoriossa ja toisen kokeen analyysit Yliopiston kotieläintieteellisen laitoksen laboratoriossa. Eri seosten kemiallinen kokoomus ja lasketut ry-arvot on esitetty taulukossa 2.

Vertailuryhmän ruokintasuunnitelma kokeessa 1 on esitetty taulukossa 3 . Kokeessa heran kulutus jäi kuitenkin jonkinverran ennakolta laskettua määrää pienemmäksi. Valkuaisen puutetta kokeen aikana ei todennäköisesti kuitenkaan esiintynyt. Tämän varmistamiseksi toisessa kokeessa käytettiin jonkinverran runsaammin valkuaista sisältävää seosta. Muuten kokeessa 2 noudatettiin samaa ruokintasuunnitelmaa kuin kokeessa 1.

Taulukko 3. Vertailuryhmän ruokintasuunnitelma

Table 3. Feeding scheme for the standard group.

\begin{tabular}{|c|c|c|c|c|c|c|c|}
\hline \multirow[t]{3}{*}{$\begin{array}{l}\text { Elopaino } \\
\text { Live weight }\end{array}$} & \multirow{2}{*}{\multicolumn{2}{|c|}{$\begin{array}{l}\text { Ravinnon tarve } \\
\text { Hanssonin muk. } \\
\text { Required according } \\
\text { to the standards } \\
\text { of Hansson }\end{array}$}} & \multirow{3}{*}{$\begin{array}{l}\text { Kuoritt. } \\
\text { maitoa } \\
\text { Skim milk }\end{array}$} & \multirow{2}{*}{$\begin{array}{l}\text { Heraa } \\
\text { Whey }\end{array}$} & \multirow{3}{*}{$\begin{array}{l}\text { Väkirehu- } \\
\text { seosta } \\
\text { Dry feed } \\
\text { mixture }\end{array}$} & \multicolumn{2}{|c|}{$\begin{array}{l}\text { Yhteensä } \\
\text { Total }\end{array}$} \\
\hline & & & & & & \multirow[t]{2}{*}{$\begin{array}{l}R y \\
\text { Sc.fu. }\end{array}$} & $\begin{array}{l}\text { Sv. } \\
\text { Dig.prot. }\end{array}$ \\
\hline & $\begin{array}{r}\text { Ry } \\
\text { Sc.fu. }\end{array}$ & $\begin{array}{c}\text { Sv } \\
\text { Dig.prot. } \\
\text { g/pv }\end{array}$ & & $\mathrm{kg}$ & & & g \\
\hline $15-20$ & 0.9 & 117 & 2.0 & 1.5 & 0.5 & 0.85 & 120 \\
\hline \multirow[t]{2}{*}{$20-25$} & 1.1 & & 2.0 & 3.5 & 0.6 & 1.08 & 146 \\
\hline & & 148 & & & & & \\
\hline $25-30$ & 1.3 & & 1.0 & 5.0 & 0.8 & 1.21 & 146 \\
\hline \multirow[t]{2}{*}{$30-35$} & 1.5 & & 1.0 & 10.0 & 0.9 & 1.65 & 200 \\
\hline & & 192 & & & & & \\
\hline $35-40$ & 1.7 & & & 10.0 & 1.2 & 1.77 & 196 \\
\hline \multirow[t]{2}{*}{$40-45$} & 1.9 & & & 12.5 & 1.2 & 1.95 & 218 \\
\hline & & 220 & & & & & \\
\hline $45-50$ & 2.1 & & & 15.0 & 1.2 & 2.12 & 241 \\
\hline \multirow[t]{2}{*}{$50-55$} & 2.3 & & & 20.0 & 1.1 & 2.38 & 277 \\
\hline & & 250 & & & & & \\
\hline $55-60$ & 2.5 & & & 20.0 & 1.1 & 2.38 & 277 \\
\hline $60-65$ & 2.6 & & & 23.0 & 1.1 & 2.59 & 304 \\
\hline \multirow[t]{2}{*}{$65-70$} & 2.7 & & & 23.0 & 1.1 & 2.59 & 304 \\
\hline & & 265 & & & & & \\
\hline \multirow[t]{2}{*}{$70-75$} & 2.8 & & & 25.0 & 1.2 & 2.82 & 331 \\
\hline & & 270 & & & & & \\
\hline $75-80$ & 2.9 & & & 25.0 & 1.2 & 2.82 & 331 \\
\hline \multirow[t]{2}{*}{$80-85$} & 3.0 & & & 27.0 & 1.3 & 3.05 & 357 \\
\hline & & 270 & & & & & \\
\hline $85-90$ & 3.1 & & & 27.0 & 1.4 & 3.14 & 366 \\
\hline \multirow[t]{2}{*}{$90-95$} & 3.2 & & & 28.0 & 1.5 & 3.30 & 384 \\
\hline & & 290 & & & & & \\
\hline $95-100$ & 3.3 & & & 28.0 & 1.7 & 3.48 & 402 \\
\hline
\end{tabular}




\section{Koetulokset}

Eri porsasryhmien kasvun kehitys kokeessa 1 on esitetty kuviossa 1 ja kokeessa 2 kuviossa 2. Tulostaso on kauttaaltaan suhteellisen alhainen. Porsaiden terveydentila oli kokeen aikana silmämääräisesti hyvä, mutta vielä keskeneräinen sikala oli ajoittain kylmä ja kostea. Viimeksimainittu seikka on voinut osaltaan hidastaa kasvua ja vaikuttaa tulostasoon.

Kaikkien koeryhmien keskimääräiset lisäkasvut on esitetty taulukossa 4 . Kuten tästä taulukosta ja kuviosta 1 ja 2 ilmenee kasvunopeus oli automaattiruokinnalla olleissa ryhmissä huomattavasti suurempi kuin vastaavissa vertailuryhmissä, ja automaattiryhmät valmistuivat teurastuskuntoon noin $25-30 \mathrm{pv}$. aikaisemmin kuin käsin ruokitut vertailuryhmät.

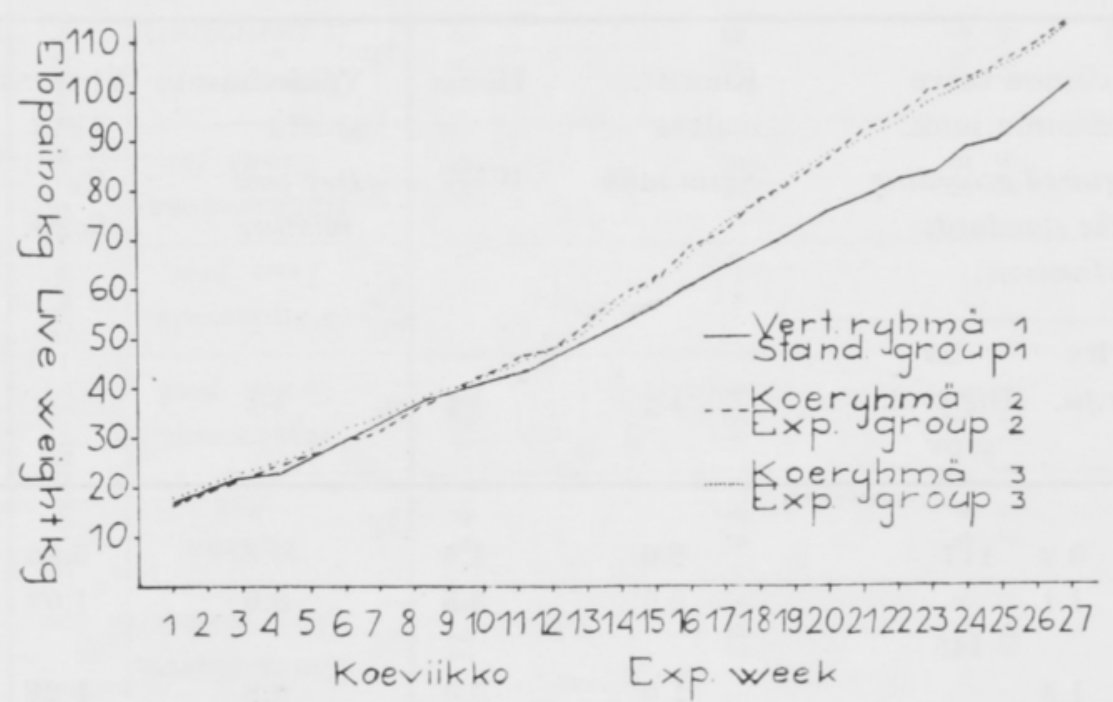

Kuvio 1. Keskimääräinen lisäkasvu ryhmittäin kokeessa 1.

Fig. 1. The average weight increase per each group in the first trial.

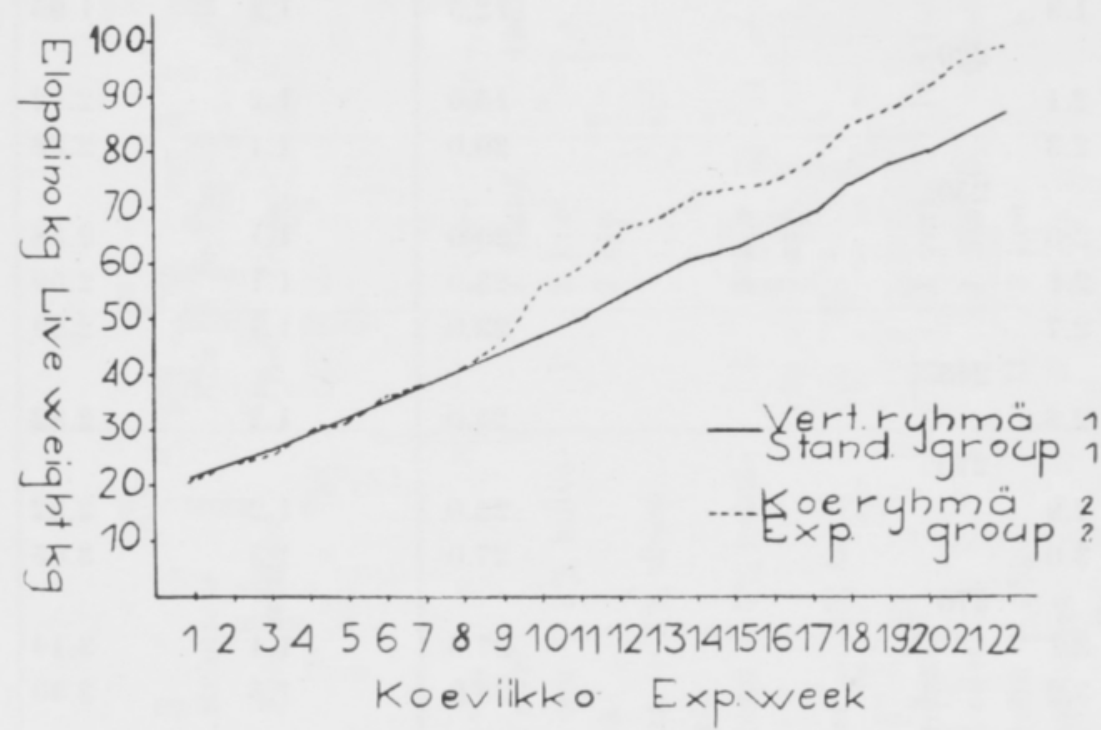

Kuvio 2. Keskimääräinen lisäkasvu ryhmittäin kokeessa 2.

Fig. 2. The average weight increase per each group in the second trial. 
Keskimääräinen rehunkulutus ryhmittäin ja suhteessa elopainon lisäykseen on esitetty taulukossa 5. Näitä tuloksia arvosteltaessa on huomattava, että yksi toisen kokeen koeryhmän sioista sairastui pari viikkoa ennen teurastusta (Tulehdusta maksassa ja pleurakalvoissa) ja taulukossa esitetty tulos antaa tämän takia jossakin määrin liian epäedullisen kuvan ryhmän 2 saaman ruokinnan vaikutuksesta.

Teurastustulokset ja keskimääräinen rehunkulutus tuotettua teuraspainokiloa kohden on esitetty taulukossa 6 . Viimeksimainittu luku on laskettu vähentämällä lopullisesta teuraspainosta alkupaino vähennettynä 35 prosentiksi arvioidulla teurastappiolla. Taulukon 6 johdosta on myös huomattava, että toisen kokeen leikeryhmän eläimistä yksi sairastui ennen kokeen päättymistä kuten edellä on mainittu.

Teurastuksen yhteydessä maisteri J. Partanen on hyväntahtoisesti suorittanut teurasarvostelun Sikatalouskoeasemalla noudatetun menetelmän mukaisesti. Nämä tulokset on pääkohdiltaan esitetty myös taulukossa 6 .

\section{Koetulosten tarkastelua}

Edellä esitetyt ruokintakokeet oli alunperin suunniteltu automaattiruokinnan teknillistä järjestelyä ja lähinnä sopivien väkirehun syönnin hidastajien löytämistä silmällä pitäen. Tässä suhteessa tähänastiset kokeet ovat antaneet melko selvän tuloksen. Verrattain runsaastikin kuitua sisältävään väkirehuseokseen voidaan heraruokinnan yhteydessä vielä lisätä kuivaleikettä tai jauhettua heinää ilman, että tällä toimenpiteellä on ilmeisesti haitallista vaikutusta rehun hyväksikäyttöön. Verrattain pienilläkin karkearehulisillä on jo väkirehun kulutusta vähentävä ja heran kulutusta lisäävä vaikutus. Niinpä $5 \%$ :n suuruisilla heinäjauho- ja kuiva-

Taulukko 4. Lisäkasvu ryhmittäin.

Table 4. Weight increase in average per each group.

\begin{tabular}{|c|c|c|c|c|c|c|c|c|}
\hline Koe & Ryhmä & Rehu & $\begin{array}{l}\text { Leik- } \\
\text { koja }\end{array}$ & $\begin{array}{l}\text { Emak- } \\
\text { koja }\end{array}$ & $\begin{array}{l}\text { Alku- } \\
\text { paino }\end{array}$ & $\begin{array}{l}\text { Loppu- } \\
\text { paino }\end{array}$ & \multirow{2}{*}{\multicolumn{2}{|c|}{$\begin{array}{l}\text { Lisäkasvu } \\
\text { Increase in weight } \\
\text { Yht. Eläintä kohti } \\
\text { Tot. Per animal }\end{array}$}} \\
\hline Trial & Group & \multirow[t]{2}{*}{ Feed } & \multirow{2}{*}{$\begin{array}{l}\text { Castra- } \\
\text { ted males } \\
\quad \mathrm{kpl}\end{array}$} & \multirow{2}{*}{$\begin{array}{c}\text { Females } \\
\text { kpl }\end{array}$} & \multirow{2}{*}{$\begin{array}{c}\text { Initial } \\
\text { Weight } \\
\mathrm{kg}\end{array}$} & \multirow{2}{*}{$\begin{array}{c}\text { Final } \\
\text { Weight } \\
\text { kg }\end{array}$} & & \\
\hline & & & & & & & $\mathrm{kg}$ & $\mathrm{g} / \mathrm{pv}$ \\
\hline \multirow[t]{6}{*}{ I } & 1 vert. & \multirow{2}{*}{$\begin{array}{l}\text { Perusrehu } \\
\text { Basal feed }\end{array}$} & 7 & 5 & 14.7 & 100.5 & 85.8 & 449 \\
\hline & 1 stand. & & & & & & & \\
\hline & 2 autom. & $" \quad+$ leike & 6 & 6 & 14.9 & 113.5 & 98.6 & 516 \\
\hline & & + dried pulp & & & & & & \\
\hline & 3 autom. & + heinä & 7 & 5 & 15.9 & 113.5 & 97.6 & 511 \\
\hline & $2 \quad "$ & $" \quad+$ hay meal & & & & & & \\
\hline \multirow[t]{4}{*}{ II } & 1 vert. & \multirow{2}{*}{$\begin{array}{l}\text { Perusrehu } \\
\text { Basal feed }\end{array}$} & 7 & 3 & 19.2 & 97.4 & 78.2 & 444 \\
\hline & 1 stand. & & & & & & & \\
\hline & 2 autom. & $" \quad+$ leike & 4 & 6 & 19.0 & 109.4 & 90.6 & 515 \\
\hline & $2 \quad "$ & $\begin{array}{l}\quad+\text { dried pulp } \\
\text { with molasses }\end{array}$ & & & & & & \\
\hline
\end{tabular}


Taulukko 5. Rehunkulutus.

Table 5. Feed consumption.

\begin{tabular}{|c|c|c|c|c|c|c|c|c|c|}
\hline \multirow[t]{2}{*}{$\begin{array}{l}\text { Koe } \\
\text { Trial }\end{array}$} & \multirow[t]{2}{*}{$\begin{array}{l}\text { Ryhmä } \\
\text { Group }\end{array}$} & \multirow{2}{*}{$\begin{array}{l}\text { Ruokinta- } \\
\text { päiviä } \\
\text { Days fed }\end{array}$} & \multicolumn{4}{|c|}{$\begin{array}{l}\text { Rehunkulutus } \\
\text { Feed cousnmption }\end{array}$} & \multicolumn{2}{|c|}{$\begin{array}{c}\text { Rehussa yht. } \\
\text { In total }\end{array}$} & \multirow{2}{*}{$\begin{array}{l}\text { Lisäkasvukiloa } \\
\text { kohden } \\
\text { Per each kg } \\
\text { weight increase } \\
\text { ry } \\
\text { Sc.fu. }\end{array}$} \\
\hline & & & $\begin{array}{r}\mathrm{Ku} \\
\text { mait } \\
\text { Skim } \\
\mathrm{kg}\end{array}$ & $\begin{array}{l}\text { or. } \\
\text { milk }\end{array}$ & $\begin{array}{l}\text { Heraa } \\
\text { Whey } \\
\text { kg }\end{array}$ & $\begin{array}{c}\text { Väkirehua } \\
\text { Dry feed } \\
\text { kg }\end{array}$ & $\begin{array}{c}\text { Ry } \\
\text { Sc. } f u \text {. }\end{array}$ & $\begin{array}{c}\text { Sv } \\
\text { Dig.prot } \\
\mathrm{g} / \mathrm{kg}\end{array}$ & \\
\hline \multirow[t]{3}{*}{ I } & $\begin{array}{l}1 \text { vert. } \\
1 \text { stand }\end{array}$ & 191 & 95 & & 2235 & 194.6 & 346.7 & 39.7 & 4.04 \\
\hline & $\begin{array}{l}2 \text { leike } \\
2 \text { dried pulp }\end{array}$ & 191 & 84 & & 2642 & 238.4 & 412.7 & 46.2 & 4.19 \\
\hline & $\begin{array}{l}3 \text { heinä } \\
3 \text { hay meal }\end{array}$ & 191 & 84 & & 2164 & 242.6 & 378.7 & 42.4 & 3.88 \\
\hline \multirow[t]{2}{*}{ II } & $\begin{array}{l}1 \text { vert. } \\
1 \text { stand }\end{array}$ & 176 & 68 & & 2506 & 190.0 & 348.9 & 44.3 & 4.46 \\
\hline & $\begin{array}{l}2 \text { leike } \\
2 \text { dried pulp }\end{array}$ & 176 & 69 & & 2429 & 265.0 & 406.6 & 50.7 & $(4.49)$ \\
\hline
\end{tabular}

Taulukko 6. Teurastustulokset ja rehunkulutus suhteessa laskettuun teuraspainon lisäykseen Table 6. Dressing results and the feed consumption in proportion to the calculated increase in the carcass weight.

\begin{tabular}{|c|c|c|c|c|c|c|c|c|c|c|c|}
\hline \multirow[t]{3}{*}{$\begin{array}{l}\text { Koe } \\
\text { Trial }\end{array}$} & \multirow[t]{3}{*}{$\begin{array}{l}\text { Ryhmä } \\
\text { Group }\end{array}$} & \multirow{3}{*}{$\begin{array}{c}\text { Elopaino } \\
\text { Live } \\
\text { weight } \\
\\
\mathrm{kg}\end{array}$} & \multirow{3}{*}{$\begin{array}{c}\text { Teuras- } \\
\text { paino } \\
\text { Carcass } \\
\text { weight } \\
\\
\text { kg }\end{array}$} & \multirow{2}{*}{\multicolumn{2}{|c|}{$\begin{array}{c}\text { Teurastus- } \\
\text { tappio } \\
\text { Lost in } \\
\text { dressing }\end{array}$}} & \multicolumn{4}{|c|}{$\begin{array}{l}\text { Selkäsilavan paksuus, cm } \\
\text { Thickness of back fat, cm }\end{array}$} & \multirow{3}{*}{$\begin{array}{l}\text { Lihak- } \\
\text { kuus } \\
\text { Lean } \\
\text { to fat } \\
\text { points }\end{array}$} & \multirow{3}{*}{$\begin{array}{c}\mathrm{Ry} / \mathrm{kg} \\
\text { teuras- } \\
\text { painon } \\
\text { lis. } \\
\text { Sc.fu./kg } \\
\text { increase in } \\
\text { carcass } \\
\text { weight }\end{array}$} \\
\hline & & & & & & & & & & & \\
\hline & & & & $\mathrm{kg}$ & $\%$ & 1 & 2 & 3 & $\begin{array}{l}\text { keskim. } \\
\text { Average }\end{array}$ & & \\
\hline \multirow[t]{3}{*}{ I } & $\begin{array}{l}1 \text { vert. } \\
1 \text { stand }\end{array}$ & 100.5 & 72.2 & 28.3 & 28.2 & 3.8 & 2.4 & 2.5 & 2.9 & 13.3 & 5.54 \\
\hline & $\begin{array}{l}2 \text { leike } \\
2 \text { dried pulp }\end{array}$ & 113.5 & 86.3 & 27.2 & 24.0 & 4.5 & 2.8 & 3.3 & 3.5 & 12.3 & 5.39 \\
\hline & $\begin{array}{l}3 \text { heinä } \\
3 \text { hay meal }\end{array}$ & 113.5 & 85.0 & 28.5 & 25.1 & 4.5 & 3.1 & 3.6 & 3.7 & 13.3 & 5.07 \\
\hline \multirow[t]{2}{*}{ II } & $\begin{array}{l}1 \text { vert. } \\
1 \text { stand. }\end{array}$ & 97.4 & 71.6 & 25.8 & 26.9 & 4.2 & 2.8 & 3.2 & 3.4 & 12.4 & 5.90 \\
\hline & $\begin{array}{l}2 \text { leike } \\
2 \text { dried pulp }\end{array}$ & 109.4 & 84.1 & 25.3 & 23.3 & 5.0 & 3.5 & 4.1 & 4.2 & 11.7 & $(5.67)$ \\
\hline
\end{tabular}


leikelisäyksillä on saavutettu jo likimain yhtä suuri heran kokonaiskulutus kuin käsin ruokinnalla.

Eri kasvuvaiheissa saatuja tuloksia keskenään vertaamalla voidaan myös todeta, että karkearehun lisäämisellä sikojen väkirehuseoksiin on saavutettu huomattavampaa etua vasta noin 40 kilon elopainorajasta alkaen. Lisäksi tulokset näyttävät vielä voivan parantua, jos väkirehuseoksen kuitupitoisuutta lisätään asteittain niin, että se on 40 kilon painorajassa vain noin $6 \%$ ja sitten vähitellen nostetaan 10 - 11 prosenttiin.

Parhaat tulokset näissä kokeissa saatiin heinäjauholisäyksellä. Nuorena porsaat näyttävät pyrkivän sylkemään heinäjauhoja suustaan, varsinkin jos heinäjauho on karkeaa. Myöhemmin siat taas syövät sitä hyvällä ruokahalulla. Heinäjauhon sopivin määrä 40-100 kg painavien herasikojen kuivarehuseoksessa näyttää olevan kasvuvaiheesta ja väkirehun kuitupitoisuudesta riippuen $5-15 \%$ seoksen määrästä. Runsas heinäjauhoruokinta voi aiheuttaa rasvassa jonkinverran keltaista väriä. Tämän estämiseksi osa heinäjauhoista voidaan korvata sellaisilla väkirehuilla, jotka sisältävät suhteellisen runsaasti kuitua taikka kuivaleikkeellä.

Syystä että koe-eläimet on teurastettu yhtaikaa eri kasvuvaiheess, ruhojen laatuarvostelun tulokset eivät ole keskenään täysin verrannollisia. Suuremmasta elopainosta huolimatta lihakkuus oli ensimmäisen kokeen automaattiryhmien koe-eläimillä yhtä hyvä kuin vertailuryhmällä. Ero selkäsilavan paksuudessakin on suhteellisesti pieni. Lisäksi on todettava, että rehun suhteellinen hyväksikäyttö on heinäjauhoryhmällä ollut keskimäärin parempikin kuin käsin ruokitulla vertailuryhmällä.

Edellä esitetyn perusteella näyttääkin siltä, että erityisesti meijerisikaloissa vapaa automaattiruokinta on mahdollista järjestää niin, että heran ja väkirehun kulutus ovat tarpeen mukaan välillisesti säädettävissä. Tällöin automaattiruokinnalla voidaan myös vaikuttaa ruhojen lihakkuuteen ja silavan paksuuteen yhtä tehokkaasti kuin sikoja käsin ruokittaessa.

\section{Yhteenveto ja päätelmät}

Meijerien Keskusosuusliike Valion Ylitornion meijerin sikalassa suoritetun kahden ruokintakokeen sekä käytännön olosuhteissa tekemiensä havaintojen nojalla kirjoittajat ovat päätyneet seuraaviin johtopäätöksiin.

Väkirehujen syöntiä voidaan meijerisikaloissa tarvittavassa määrin rajoittaa ja heran kulutusta nostaa lisäämällä kuivarehuautomaateista vapaasti syötettävään väkirehuseokseen 5-15\% heinäjauhoja tai kuivattua sokerijuurikasleikettä.

Karkearehulisien ei tarvitse alentaa rehun hyväksikäyttöä ja tuotantovaikutusta, jos samanaikaisesti huolehditaan siitä, että koko rehuánnoksen (hera mukaanluettuna) kuiva-aineen raakakuitupitoisuus ei nouse haitallisen suureksi.

Edellä esitettyjä periaatteita soveltamalla tuotteiden laatua ja erityisesti eläinten lihavuusastetta, lihakkuutta ja silavan paksuutta voidaan meijerisikaloissa automaattiruokinnalla säätää suunnilleen yhtä tehokkaasti kuin eläimiä käsin ruokittaessa. 


\section{KIRJALLISUUTTA}

(1) Axelsson, Joel \& Eriksson, Sture, 1953. The optimum crude fiber level in ration of growing pigs. J. Animal Sci. 12: 881-891.

(2) Brugman, H. H., 1950. The effect of plane of nutrition on the carcass quality of a line of swine based on a Chester White and Danish Landrace cross. Ibid. 9: 602 - 607.

(3) Bull, S. \& Longwell, J. H., 1929. Swine Type Studies. II. Type in Swine as Related to Quality of Pork. Ill. Agric. Exp. Sta. Bull. 322.

(4) Crampton, E. W., Ashton, G. C. \& Lloyd, L. E., 1954. The effect of restricting feed intake of market hogs during the finishing period on the quality of the bacon carcass. J. Animal Sci. 13: $321-326$.

(5) Gregory, K. E. \& Dickerson, G. E., 1952. Influence of heterosis and plane of nutrition on the rate and economy of gains, digestion and carcass composition of pigs. Missouri Agric. Exp. Sta. Res. Bull. 493: 48.

(6) Hankins, O. G., 1945. Quality in Meat and Meat Products. Ind. \& Engin. Chem. 37, 3: 220-223.

(7) Hutchinson, K. J., 1953. The influence of feeding practice on baconer carcass quality. Queensland Agric. J. 77: $37-43$.

(8) Mc Meekan, C. P., 1940. Growth and development in the pig, with special reference to carcass quality characters. Part. III. Effect of the plane of nutrition on the form and composition of the bacon pig. J. Agric. Sci. 30: 511-569.

(9) —- 1941. Growth and development in the pig with particular reference to carcass quality. J. Agric. Sci. 31: 1-49.

(10) Mc Meekan, C. P. \& Hammond, J., 1939. Improvement of carcass quality in pigs. J. Min. Agric. 46: 238 .

(11) Mendel, L. B., 1930. Some relations of diet to fat deposition in the body. Yale J. Biol. Med. 3: 107 .

(12) Nordfeldt, S., 1946. Försök med stigande mängder växttråd i fodret till växande gödsvin. Lantbr.skolans husdjförs.anst. Förh.medd. 57. Norrtälje.

(13) Poijärvi, I., Partanen, J. \& Pakarinen, Sirkka, 1950. Uusi ruokintakoe heran rehuarvon selvittämiseksi sikojen ruokinnassa. Valt. maatal.koetoim. julk. 133: 1-18.

(14) Report of the Minister of Agriculture for the Dominion of Canada for the year ended March 31 , 1946: $123-124$.

(15) Whatley, Jr., J. A., Gard, D. I., Whiteman, J. V. \& Hillier, J. C.. 1955. Meat-type hog production, influence of breeding and energy content of the ration on pork cracasses. Oklahoma Agric. Exp. Sta. Bull. B-398: 11.

S U M M A R Y :

\section{EXPERIMENTS ON THE AUTOMATIC FEEDING SYSTEM IN CHEESE PLANT PIGGERIES,}

P. SAarinen, E. SyrJänen and VUOKKo Hyvärinen

Department of Animal Husbandry, University of Helsinki

On the basis of two feeding trials carried out in Lappland in a cheese plant piggery owned by the Finnish Cooperative Dairies' Association Valio the following conclusions were drawn.

The consumption of dry feed can be decreased and the consumption of whey increased by supplementation the feed used in automatic feeders with hay meal or dry beet pulp $(5-15 \%)$.

If the crude fiber content of the dry matter in the whole ration (whey included) does not exceed certain limits the roughage supplementation does not decrease the feed utilization.

Balancing the rations on the basis of these two factors the carcass quality, and the lean to fat ratio can be controlled also in self-fed animals. 